\title{
Isolation and Identification of Nocardia spp. from the local soils in diyala province
}

\author{
Sarmad Q Mohammed (Msc) ${ }^{1}$, Idriss S Jaleel(Msc) ${ }^{2}$ and Mohammed K
}

$\operatorname{Abbas}(\mathrm{Msc})^{3}$

\begin{abstract}
Background: Nocardia spp. belongs to the family Nocardiaceae , are obligatory aerobic, Gram-positive ,non-spore forming, and non-motile ,actinomycete that form filamentous branched cells normally are saprophytes of soil, Nocardia is a rare bacterial opportunistic known for its ability to cause a wide range of clinical diseases in humans and animal Objective:To using phenotypic methods from soil samples of Diyala province and study resistance of to some antibiotic.

Patients and Methods: Collected ( 50 ) soil samples from the various regions of diyala province The samples included various ecosystems, rural areas and urban areas and culture of samples on the media trypton soya agar which containing $5 \mu \mathrm{g} / \mathrm{mL}$ tetracycline, $50 \mu \mathrm{g} / \mathrm{ml}$ nystatin and $5 \% \mathrm{NaCl}$, and diagnosed according to colonial characteristics microscopic examination, biochemical tests isolates were selected to measure their resistance to some of, the antibiotic.

Results: In the rural area had the highest positive growth. 15samples (60\%) showed positive growth and 10 samples (40\%).showed negative growth in as for the urban area, only two samples (8\%) showed positive growth and 23 samples (92\%) showed negative growth of bacterial, In this study,isolation different types of Nocardia spp. from soil in different areas of diyala province, and used trypton soya agar (TSA) medium containing two antibiotics tetracycline and nystatin, It was the highest percentage of antibiotic resistance in against antibiotic Tobramycin which reached (38.40\%) while was the lowest percentage resistance in the antibiotic Gentamicin which reached (15.30\%).

Conclusion: Due to pathogenicity and species diversity of Nocardia, using phenotypic tests are essential for identification of Nocardia species. Isolation and identification of Nocardia spp. from soil of different regions can help to enhance our understanding of epidemiological and ecological of the pathogenic Nocardia species. The isolation of species resistance to antibiotic means that they have a predisposition to the pathogenesis of the human.
\end{abstract}

Key words: Nocardia, Antibiotics, TSA, soil, rural, urban.

Corresponding Author: sarmadbio6@gmail.com

Received: $27^{\text {th }}$ May 2018

Accepted: $24^{\text {th }}$ June 2018

https://doi.org/10.26505/DJM

${ }^{1,2,3}$ College Assistant lecturer -Middle Technical University (MTU)- Institute of Medical Technology-

Baquba-Diyala-Iraq.

\section{Introduction}

Nocardia spp. belongs to the family form filamentous branched cells which is Nocardiaceae, and members of the genus are obligatory aerobic, Gram-positive ,non-spore forming, and non-motile, actinomycete that divided into multi-form shapes in the form of a rod or a coccai . These bacteria are relatively slow growing [1,2].Catalase and 
urease positive bacteria that belong to Actinomycetes group [3]. Soil is one of the best sources of Nocardia spp. isolation, It is widely spread in dry locations, especially during dust storms. These organisms can also exist in other environments such as air, water and plants [4]. Nocardia does not belong to normal human flora, normally are saprophytes of soil and have a role in the decay of organic plant material. However, Nocardia have increasingly been isolated as infectious agents in immune-suppressed patients[5,6]. There are different factors such as $\mathrm{pH}$, soil type, climate, temperature and humidity can affect the abundance of Nocardia spp. isolates from soil[7]. Nocardia is a rare bacterial opportunistic known for its ability to cause a wide range of clinical diseases in humans and animals as these bacteria cause disease Nocardiosis Which may be pulmonary(Pulmonary nocardiasis)or diffuse systemically(systemic nocardiasis) or a skin (Cutaneous nocardiasis), as well as Nocardia central nervous system, It rarely infects other organs such as kidneys, joints and eyes. So far more than 50 species of Nocardia have been described, among them the most common ones which are considered to be the most common pathogens for humans and animals $N$. farcinica, $N$. abscessus, $N$. asteroides, $N$. brasiliensis $N$. otitidiscaviarum $N$. transvalensis $[1,4,8,9]$.

Pneumonia Nocardiasis is the most common type of infection, which occurs through the entry of these germs with the dust particles contaminated by the respiratory system through inhalation, Which occur in patients with immunodeficiency, including sarcoidosis, chronic granulomatous, diabetes and AIDS, and trauma disease[10, 11]. Some species are more prevalent in geographical locations with a specific climate, Nocardia brasiliensis, usually associated with cutaneous infection and is more commonly isolated in areas with tropical or subtropical climates in the southwestern or southeastern United States[12]. Isolation and identification of Nocardia spp. using phenotypic methods from soil samples of Diyala province and study resistance of some antibiotic

\section{Patients and Methods}

\section{Sample collection}

In our study collected [50] soil samples from the various regions of diyala province, included (Baquba, Khalis, Muqdadiya, Baladrouz, Khanaqin), As shown in Table (1) during the period from 1/10/2017 to $30 / 2 / 2018$, The samples included various ecosystems, rural areas including( gardens ,agricultural fields, animal home and beaches of rivers).and urban areas including (non-agricultural soil, along the roads and streets and squares). The surface layer of the soil was removed 3-5 cm using a sterile knife and taken $20 \mathrm{~g}$ of soil using a sterile spoon into a sterile nylon bag with the following information installed: the name of the area, the nature of the land and the date of taking the form. The samples were then transferred to the laboratory within 48 hours. and stored in the refrigerated until they were used and the insulation was carried out. 
Table(1): Areas of diyala Province from which samples were collected.

\begin{tabular}{||c||c||c||}
\hline Place of sampling & Sample rural number & Sample urban number \\
\hline \hline Baquba & 5 & 5 \\
\hline \hline Khalis & 5 & 5 \\
\hline \hline Muqdadiya & 5 & 5 \\
\hline \hline Baladrouz & 5 & 5 \\
\hline \hline Khanaqin & 5 & 5 \\
\hline \hline Total & 25 & 25 \\
\hline
\end{tabular}

Isolation of Nocardia spp.from soil samples

Add [0.1] g of soil to [10] $\mathrm{ml}$ sterile saline solution and shake the dilution strongly and leave to be precipitate for (30) minutes, and made a series of diluting for the samples [1:10 - 6:10], and was spread[0.5] Ml of dilution $3: 10$ and $4: 10$ on TSA dishes containing $5 \mu \mathrm{g} / \mathrm{mL}$ tetracycline, $50 \mu \mathrm{g} / \mathrm{ml}$ nystatin and $5 \% \mathrm{NaCl}$. The dishes were incubated at a temperature of $37^{\circ} \mathrm{C}$ and examined daily for up to 7 days for growth of Nocardia Spp. ,the media of trypton soya agar (TSA) with a mixture of $5 \mu \mathrm{g}$ of tetracycline, $50 \mu \mathrm{g}$ of nastatin and $5 \%$ of sodium chloride excellent media for isolating Nocardia Spp. [13].

\section{Identification of soil isolates}

Isolates were diagnosed according to Quinn et.al. [14], and Cawon and Steel [15] based on colonial characteristics microscopic examination ,Colony characteristic were studied using tryptic soy agar plates after incubation at $37^{\circ} \mathrm{C}$ Smears made from pure colonies and stained with gram stains and then examined microscopically for the presences of branching filaments or coccobacilli forms . and all biochemical tests were done such as Urease tests, Catalase Test, Casein degradation, Tyrosine degradation, Starch degradation, utilization of Xanthine and Sorbitol as well as Growth at $45^{\circ} \mathrm{C}$ test.

\section{Antibiotic resistance}

Nocardia isolates were selected to measure their resistance to the antibiotics Shown in

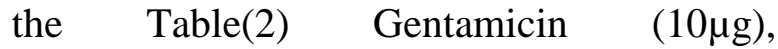
Amikacin $(30 \mu \mathrm{g}), \quad$ Tobramicin $(10 \mu \mathrm{g})$ and Erythromicin $(15 \mu \mathrm{g})$,by using modified Kirby Bauer disc diffusion technique (Kirby and Bauer) [16]. Then the diameters of the inhibition zones were measured around each disc, Considered the bacteria Sensitive or or Resestance, according to the standard specifications in CLSI,2012[17]. 
Table(2): Antibiotics used in the study.

\begin{tabular}{|c|c|c|c|}
\hline \multirow[b]{2}{*}{ Antibiotic } & \multirow{2}{*}{$\begin{array}{c}\text { Antibiotic } \\
\text { Concentration } \\
\mu \mathrm{g} / \mathrm{ml}\end{array}$} & \multicolumn{2}{|c|}{ Diameters of standard inhibition zones / $\mathrm{mm}$} \\
\hline & & Sensitive (S) & Resistance (R) \\
\hline Gentamicin (GM) & $10 \mu \mathrm{g}$ & $15 \leq$ & $12 \leq$ \\
\hline Amikacin ( AN ) & $30 \mu \mathrm{g}$ & $17 \leq$ & $14 \leq$ \\
\hline Tobramycin( TOB ) & $10 \mu \mathrm{g}$ & $15 \leq$ & $12 \leq$ \\
\hline Erythromycin( Ery ) & $15 \mu \mathrm{g}$ & $21 \leq$ & $15 \leq$ \\
\hline
\end{tabular}

\section{Results}

\section{Isolation}

As shown in Table(3) The total number of samples was [50] samples distributed to rural region and urban region with [25] samples per region. The rural area had the highest positive growth. 15samples $(60 \%)$ showed positive growth and 10 samples $(40 \%)$ showed

negative growth .In As for the urban area, only two samples (8\%) showed positive growth and 23 samples (92\%) showed negative growth of bacterial culture After culturing it on the medium of the isolation and diagnosis of Nocardia spp., which Previously prepared in the paragraphs above .

Table (3): Percentage of positive and negative growth of Nocardia spp.from different ecosystems.

\begin{tabular}{|c||c||c|c||}
\hline Total sample & Sample number & Positive growth & Negative growth \\
\hline \hline $\begin{array}{c}\text { Rural soil } \\
\text { (Agricultural) }\end{array}$ & 25 & $15(\% 60)$ & $10(\% 40)$ \\
\hline \hline $\begin{array}{c}\text { Urban soil } \\
\text { (un agricultural) }\end{array}$ & 25 & $2(8 \%)$ & $23(\% 92)$ \\
\hline
\end{tabular}

\section{Diagnosis}

The results of the microscopic examination showed as shown in Figure (1) that isolated bacterial cells was Gram-positive ,non-spore forming, and non-motile ,actinomycete that form filamentous branched cells which is divided into multi-form shapes in the form of a rod or a coccai. Biochemical tests also showed that the isolates were positive for the range of tests shown in Table (4). The results shown in Figure(2) that 12 samples (92.3\%) of the 15 samples that isolated from rural soils were identified as belonging to the Nocardia spp., and one sample $(7.6 \%)$ of the two samples isolated from urban soils were identified as belonging to the Nocardia spp. 


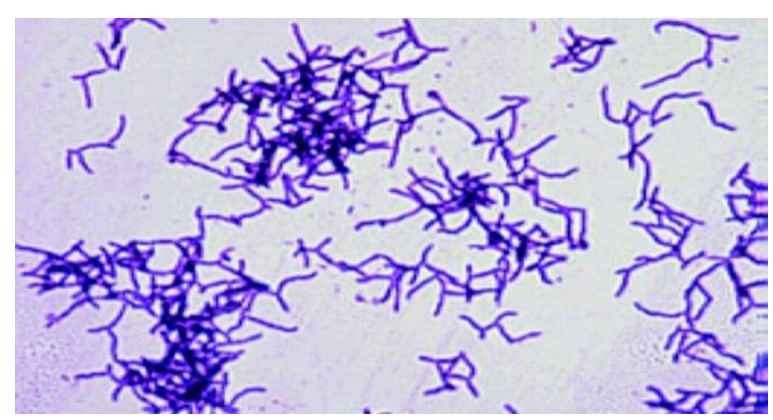

Figure (1):Microscopic examination (Gram-positive of Nocardia spp.)

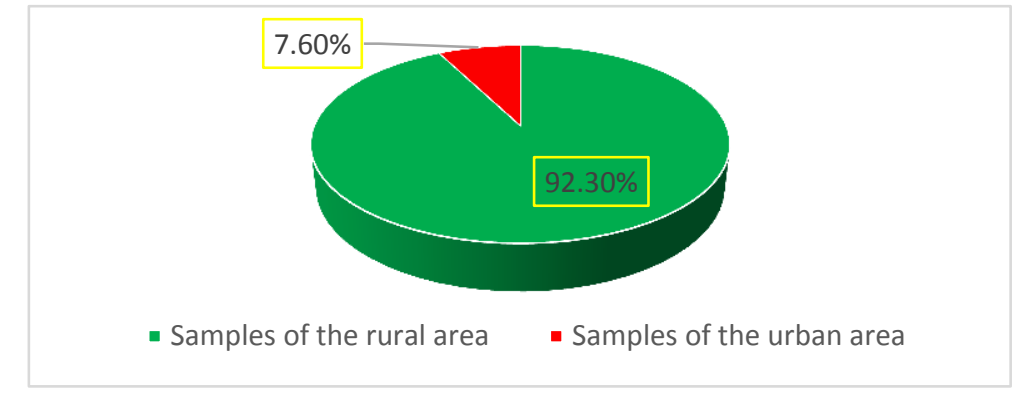

Figure (2): Percentages of isolates which diagnosed from different ecosystem.

Table (4): Biochemical reactions of the Nocardia spp. isolated from soil.

\begin{tabular}{|l||c||c|}
\hline \multicolumn{1}{|c||}{ Type of tests } & +ve sample Number & Number -ve sample \\
\hline \hline Urease tests & 13 & 0 \\
\hline \hline Catalase Test & 13 & 0 \\
\hline \hline Gelatinase Test & 13 & 0 \\
\hline \hline Casein degradation & 12 & 1 \\
\hline \hline Tyrosine degradation & 13 & 0 \\
\hline \hline Starch degradation & 13 & 1 \\
\hline \hline utilization of Xanthine & 12 & 0 \\
\hline \hline utilization of Sorbitol & 13 & 0 \\
\hline \hline Growth at $45^{\circ} \mathrm{C}$ & 13 & 0 \\
\hline \hline Growth at mannitol agar & 13 & \\
\hline
\end{tabular}

\section{Antibiotic Test}

All isolates were tested using four antibiotics. The sensitivity and resistance of isolates to antimicrobial was determined by measuring the diameter of the inhibition zone in millimetersThe results were compared with (CLSI,2012) [17]..The results shown in
Figure(3) showed a clear variation in resistance bacterial Nocardia spp. to antibiotic. It wasThe highest percentage of antibiotic resistance in the antibiotic Tobramycin which reached to $(38.40 \%)$ while was the lowest percentage resistance in the antibiotic Gentamicin which reached to $(15.30 \%)$. 


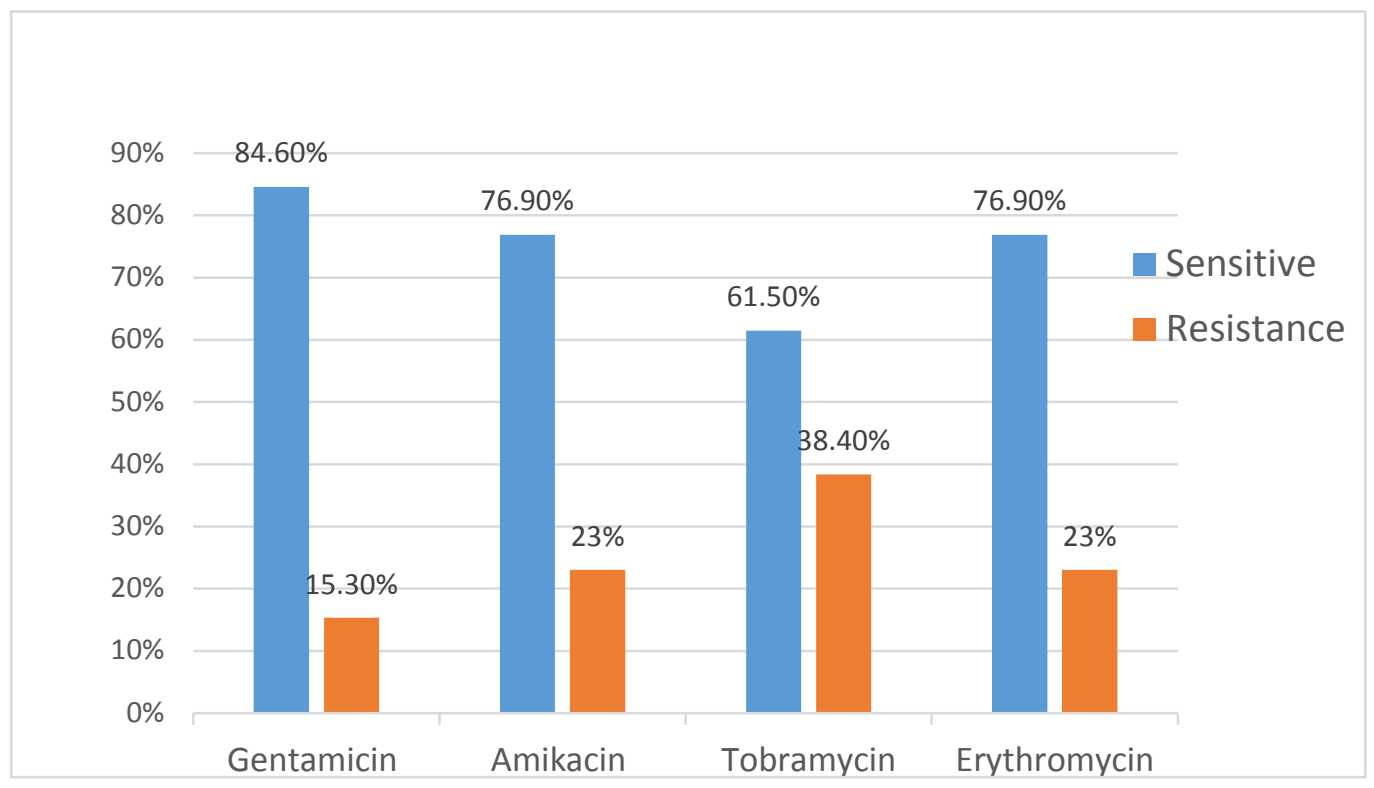

\section{Discussion}

The present study showed that there are significant differences in the percentage of isolated bacteria from rural and urban sites; these various results are depending on the geographical location, regional climate , soil type and soil ph.[19].In this study,isolation different types of Nocardia spp. Of soil in different areas of diyala province, and used trypton soya agar (TSA) medium containing two antibiotics tetracycline and nastatin, and that the researcher [18]. Used the same medium to isolate the Nocardia spp.

The highest percentage of antibiotic resistance in the antibiotic Tobramycin which reached to $(38.40 \%)$ while was the lowest percentage resistance in the antibiotic Gentamicin which reached to $(15.30 \%)$. This is due to the difference in the resistance of the antibiotic to the size of the sample and the source of isolation, as well as to the possession of bacteria resistance mechanisms, such as the capsule and the production of biofilm as well as to the occurrence of genetic mutations[16].

\section{References}

[1]Kachuei R., Mirnejad R., Emami M., Khoobdel M. Diversity and frequency of Nocardia spp. in the soil of Isfahan Province, Iran. Asian Pacific Journal of Tropical Biomedicine Trop Biomed Asian Pacific Journal of Tropical Biomedicine. 2012; 2 (6): 474- 8 .

[2]Brown-Elliott BA, Brown JM, Conville PS, Wallace RJ. Clinical and laboratory features of the Nocardia spp. based on current molecular taxonomy. Clin Microbiol Rev 2006; 19: 259-282.

[3]Zakaria A., Elwatidy S., Elgamal E. Nocardia brain abscess: severe CNS 
infection that needs aggressive management; case report. Acta neurochirurgica 2008; 150 (10): 1097- 101.

[4]Bourbour, s.; Faghri, J.; Moghim,S .Report of Nocardia species isolated from soil by $16 \mathrm{~S}$ rRNA gene sequencing method in Isfahan, Iran. Biological Journal of Microorganism, . 2015; 4(16):33-42.

[5]J. Ambrosioni, D. Lew, and J. Garbino, "Nocardiosis: updated clinical review and experience eatatertiary center,'Infection,vol. 38,no.2,pp.89-97,2010.

[6] Hashemi-Shahraki, A., Bostanabad, S.Z., Heidarieh, P., Sheikhi, N., Biranvand, M., Alavi, S.M., Titov, L.P., Khosravi, A.D. and Nojoumi, S.A. (2015) Species Spectrum of Nocardia spp. Isolated from Suspected Tuberculosis Patients. Health, 7, 847-858. http://dx.doi.org/10.4236/health.2015.77100 [7]Martinaud C, Verdonk C, Bousquet A, MacNab C, Vaylet F, Soler C, et al. Isolation of Nocardia from a pulmonary abscess reveals human immunodeficiency virus infection. J of clin microbial 2011; 49 (7): 2748-50.

[8]Fernandes,A.M.; Sluzevich,J.C.and MiraAvendano,I. Nocardia brasiliensis Infection Complicating Cryptogenic Organizing Pneumonia. 2017, Article ID 9567175, 3 page https://doi.org/10.1155/2017/9567175.

[9]Hara,H.; Wakui,F. and Ochiai,T. Disseminated Nocardia farcinica infection in a patient with systemic lupus erythematosus Journal of Medical Microbiology. (2011). 60, 847-850.

[10]Andalibi F, Fatahi Bafghi M, Heidarieh P, Rasouli Nasab M, Habibnia SH,
Pourmand MR, Eshraghi SS. Isolation and identification of Nocardia spp. using phenotypic methods from soil samples of North Khorasan province. J Med Bacterial. 2015; 4 (1, 2): pp.8-14.

[11]Hardak E, Yigla M, Berger G, Sprecher $\mathrm{H}$, Oren I. Clinical spectrum and outcome of Nocardia infection: experience of 15-year period from a single tertiary medical center. Am J Med Sci 2011.

[12]Fergie, J. E., and K. Purcell. Nocardiosis in south Texas children. Pediatr. Infect. Dis. J. 2001; 20:711-714

[13]Ali Mohammed ,R. Nocardia Isolated From Soil And Its Potential To Induce Mastitis In Goats .thesis. Faculty of Veterinary Medicine University of Khartoum, 2005:pag 74.

[14] Quinn, P. J.; Carter, M. E. ; Markey, B. K. and Carter, G. R. (1999). Mastitis. In: Quinn, P. J. (ed) Clinical veterinary microbiology. Mosby London Pp. 327 344.

[15]Cowan, S.T and Steel,K.J. (2004). Edited and rev. by Barrow, G.I., and Feltham, R.K.A., Manual for the Identification of Medical Bacteria. 3rd edition. Dock House, The water front, Cape Town 8001, South Africa.

[16]Galeel, I.,S.(2015). Isolation and Characterization of bacteria Bacillus thuringiensis and study their impact on the living standards of some of the fruit fly cucurbits Dacus ciliatus (Diptera : Tephritidae). Thesis, College of Education for Pure Sciences , Diyala University: pag 182. 
[17]CLSI. (2012 ) . Methods for Dilution Antimicrobial Susceptibility Tests for Bacteria That Grow Aerobically; Approved Standard-Ninth Edition. 32(8). CLSI, Wayne, Pennsylvania, USA. [18]Gamal Edin, O. A. (2003). Studies on caprine mastitis caused by nocardiae actinomycetes; M. V. Sc. Thesis, University of Khartoum.

[19]Martinaud C, Verdonk C, Bousquet A, MacNab C, Vaylet F, Soler C, et al. Isolation of Nocardia from a pulmonary abscess reveals human immunodeficiency virus infection. J of clin microbial 2011; 49 (7): 2748-50. 